\title{
The Effect of Fetal Exchange Transfusions with Adult Blood upon Fetal Oxygenation
}

\author{
Frederigk C. Battaglia ${ }^{[10]}$, Watson Bowes, H. Raymond MaGaughey, \\ Edgar L. Makowski and Gracomo Meschia \\ Departments of Pediatrics, Obstetrics-Gynecology, and Physiology, \\ University of Colorado School of Medicine, Denver, Colorado, USA
}

\begin{abstract}
Extract
Intrauterine exchange transfusions were conducted in fetal sheep using adult sheep as donors. Indwelling catheters in the fetus permitted sampling of blood for 8 to 36 days following the transfusion. In the first days after the procedure there was a decreased oxygen affinity of umbilical blood, an increase of about $5 \mathrm{~mm} \mathrm{Hg}$ in umbilical venous $\mathrm{O}_{2}$ tension, and a decrease of about $30 \%$ in $\mathrm{O}_{2}$ saturation. In the following weeks there was a gradual return of $\mathrm{O}_{2}$ affinity, $\mathrm{PO}_{2}$, and oxygen saturation to normal. In all of the experiments there was a good correlation between the $\mathrm{O}_{2}$ affinity of umbilical blood and the percentage of adult cells present. This correlation indicated that adult cells retained a normal $\mathrm{O}_{2}$ dissociation curve even after weeks of exposure to the new environment. Despite an increased umbilical venous $\mathrm{PO}_{2}$, the fetal reticulocyte count increased significantly after transfusion, but the oxygen capacity of umbilical blood remained within normal limits.
\end{abstract}

\section{Speculation}

These studies suggest that the correction of fetal anemia in erythroblastosis fetalis by the use of fetal blood instead of adult blood would produce a greater increase in the amount of hemoglobin capable of carrying oxygen at the low oxygen tensions characteristic of the fetal circulation.

\section{Introduction}

The first successful intrauterine transfusion of a human fetus was reported by LiLEY in 1963 [5]. Since that time many fetal transfusions have been performed for treatment of the fetus severely affected by erythroblastosis. Despite an expanding literature about this procedure, there have been no studies reported in experimental animals evaluating some of the surgical and physiological problems encountered. One of the most obvious physiologic handicaps imposed upon the fetus that undergoes transfusion is the replacement of fetal cells with adult cells having a much lower oxygen affinity.
This study was undertaken in order to determine the effects upon umbilical blood oxygenation of substituting adult whole blood for fetal blood within the circulation of fetal lambs. Experiments were performed in animal preparations in which an indwelling catheter was implanted within the umbilical vein at the time of the exchange transfusion and in which the pregnancy was allowed to continue to the point of delivery. Such preparations made possible the determination of the changes in respiratory gases within the same fetus for some weeks following intrauterine exchange transfusion. 


\section{Materials and Methods}

Pregnant Dorset and Western ewes with known gestational history were used. For spinal anesthesia, the sheep were given $6 \mathrm{mg}$ pontocaine intrathecally; this was supplemented by nembutal given intravenously. At operation, a polyvinyl catheter of internal diameter $0.58 \mathrm{~mm}$ was implanted in the umbilical vein, carried subcutaneously to the flank of the pregnant ewe, and used for obtaining repeated blood samples over a prolonged period of time from the nonanesthetized, unstressed animal. Following surgery, the catheters were irrigated daily with a dilute solution of heparin in isotonic saline. During early experiments, the exchange transfusion was performed through the umbilical venous catheter by alternately withdrawing and infusing blood in 10 to $20 \mathrm{ml}$ increments over a onehour period. Later, it was found more satisfactory to insert temporarily an additional umbilical arterial catheter; fetal blood was then withdrawn from the umbilical artery and donor adult sheep blood was infused into the umbilical venous catheter at equal rates ( $5 \mathrm{ml} / \mathrm{min}$ ).

Five hundred $\mathrm{ml}$ of donor adult sheep blood with type $B$ hemoglobin was withdrawn from a nonpregnant adult sheep and placed in standard heparinized plastic containers (heparin concentration, $4 \mathrm{U} / \mathrm{mI}$ ) one to two hours before transfusion. Blood samples were obtained from the umbilical catheter just before and immediately after the completion of the exchange transfusion. Thereafter, samples were obtained at intervals of two to four days. Each sample ( $1.8 \mathrm{ml}$ in volume) was drawn into oiled, heparinized syringes and analyzed for oxygen and $\mathrm{CO}_{2}$ content, $\mathrm{PO}_{2}, \mathrm{pH}, \mathrm{O}_{2}$ saturation, and $\mathrm{O}_{2}$ capacity. With one exception these determinations were carried out as described previously [1]

The determination of $\mathrm{O}_{2}$ saturation on samples containing a mixed population of adult and fetal cells presented some difficulties. We had shown previously that $\mathrm{O}_{2}$ saturation of fetal sheep blood could be determined spectrophotometrically using a Radiometer oximeter. Such values agreed with those obtained by measuring both the $\mathrm{O}_{2}$ content and capacity by gas chromatography [1]. Discrepancies between the two techniques, however, were observed on fetal blood samples following the exchange transfusion (table I). Furthermore, when $\mathrm{O}_{2}$ saturations were measured from the upper and lower halves of the packed red cell column following centrifugation, higher $\mathrm{O}_{2}$ saturations were always found in the upper half. Hence, the fetal and adult red cells in the mixed population of cells present in fetal circulation following exchange transfusion had been segregated by centrifugation. Zones of different optical density were frequently present in the cuvette after delivery of the lysed, packed red cell mass for spectrophotometric measurement of $\mathrm{O}_{2}$ saturation. For this reason, $\mathrm{O}_{2}$ saturations were determined by measurement of $\mathrm{O}_{2}$ content and capacity by gas chromatography, and spectrophotometric determinations of $\mathrm{O}_{2}$ saturation were not used on any mixed samples obtained from the fetal circulation following the exchange transfusion. In four samples in which adult and fetal cells were present in the mixture in approximately equal amounts, the separation of these cells by centrifugation was used for separate, direct measurements of saturation in the two cell types. Figure 1 presents the measured $\mathrm{O}_{2}$ saturations determined spectrophotometrically on the upper zone $(\underline{\underline{x}} \mid)$ and lower zone $(x)$ of the microhematocrit in order to compare the calculated $\mathrm{O}_{2}$ saturation of fetal and adult red cells in this mixed population of cells.

The percent of fetal and adult cells was determined on each sample using the technique of KLEIHAUER $e t$ al. [4] as modified by Breathinach [2]. Reticulocyte counts were performed at the same time.

\section{Results}

Fetal exchange transfusions were performed in ten ewes, four of which had twin pregnancies. In these pregnancies, umbilical vein catheters were inserted in both fetuses with the intention of using one twin as a control for the transfused fetus. In three of the four pregnancies, however, the fetuses died shortly after the procedure; in the other, labor ensued the day following the operation and both twins were born alive. For this reason, data are not presented on these pregnancies. There was a single fetus in each of the remaining six animals. In five of these six, pregnancy continued for a sufficient length of time following the procedure to allow repeated observations.

Table I. Comparison of values obtained for $\% \mathrm{O}_{2}$ saturation on blood samples containing a mixed population of fetal and adult red cells using two different methods for measurement

\begin{tabular}{cc}
\hline \multicolumn{2}{c}{$\%$ Saturation } \\
\hline Gas chromatography & Spectrometry \\
\hline 46.2 & 24.9 \\
47.6 & 27.8 \\
59.9 & 58.0 \\
67.0 & 63.5 \\
42.9 & 29.5 \\
30.1 & 29.5 \\
33.9 & 36.7 \\
41.2 & 53.2 \\
\hline
\end{tabular}


Table II. Results of exchange transfusions in sheep fetuses

\begin{tabular}{|c|c|c|c|c|c|c|}
\hline & $\begin{array}{c}\text { Animal } \\
\text { No. }\end{array}$ & $\begin{array}{c}\text { Gestational } \\
\text { age at time } \\
\text { of transfusion } \\
\text { (Days) }\end{array}$ & $\begin{array}{l}\text { Amount of } \\
\text { blood } \\
\text { exchanged } \\
\quad(\mathrm{ml})\end{array}$ & $\begin{array}{l}\% \text { Adult cells } \\
\text { at end of } \\
\text { transfusion }^{1}\end{array}$ & $\begin{array}{c}\text { Days of } \\
\text { pregnancy } \\
\text { post } \\
\text { exchange }\end{array}$ & Outcome \\
\hline Single & 56 & 112 & 205 & 74.1 & 31 & born alive \\
\hline \multirow[t]{5}{*}{ pregnancies } & 4 & 110 & 260 & 77.4 & 36 & born alive \\
\hline & $3 \mathrm{H}$ & 136 & 500 & 84.2 & 10 & born alive \\
\hline & 44 & 134 & 420 & 70.5 & 6 & fetal death in utero \\
\hline & 010 & 123 & 405 & 80.0 & 12 & born alive \\
\hline & 122 & 110 & 200 & 86.9 & 1 & born alive \\
\hline \multirow{4}{*}{$\begin{array}{l}\text { Twin } \\
\text { pregnancies }\end{array}$} & W7 & 145 & 430 & 69.0 & 1 & born alive \\
\hline & 58 & 130 & 450 & 54.2 & 5 & fetal death in utero \\
\hline & 109 & 111 & 300 & 80.1 & 1 & fetal death in utero \\
\hline & 19 & 112 & 300 & 76.0 & 8 & fetal death in utero \\
\hline
\end{tabular}

${ }_{1}$ Determined by red cell elution.

Table III. Comparison of certain variables in blood samples obtained prior to transfusion and immediately after completion of this procedure

\begin{tabular}{|c|c|c|c|c|c|c|c|c|}
\hline \multirow[b]{2}{*}{ Animal No. } & \multicolumn{4}{|c|}{ Before exchange transfusion } & \multicolumn{4}{|c|}{ After exchange transfusion } \\
\hline & $\begin{array}{c}\mathrm{O}_{2} \\
\text { saturation } \\
\%\end{array}$ & $\begin{array}{c}\mathrm{O}_{2} \\
\text { capacity } \\
\mathrm{mMol} / \mathrm{l}\end{array}$ & $\mathrm{pH}$ & $\begin{array}{c}\mathrm{PO}_{2} \\
\mathrm{~mm} \mathrm{Hg}\end{array}$ & $\begin{array}{c}\mathrm{O}_{2} \\
\text { saturation } \\
\%\end{array}$ & $\begin{array}{c}\mathrm{O}_{2} \\
\text { capacity } \\
\text { mMol/1 }\end{array}$ & $\mathrm{pH}$ & $\begin{array}{c}\mathrm{PO}_{2} \\
\mathrm{~mm} \mathrm{Hg}\end{array}$ \\
\hline 56 & 83.1 & 6.3 & 7.388 & 28.3 & 59.4 & 7.1 & 7.352 & 36.1 \\
\hline 4 & 81.1 & - & 7.474 & 25.2 & 46.2 & 5.5 & 7.418 & 27.4 \\
\hline $3 \mathrm{H}$ & 83.2 & 6.0 & 7.362 & 32.5 & 67.0 & 5.8 & 7.392 & 36.0 \\
\hline 44 & 61.5 & 8.8 & 7.410 & 19.1 & 37.9 & 6.9 & 7.398 & 22.3 \\
\hline 010 & 76.9 & 6.4 & 7.352 & 25.6 & 42.1 & 7.0 & 7.342 & 27.0 \\
\hline 122 & 88.7 & 6.5 & 7.390 & 33.9 & 55.4 & 7.0 & 7.400 & 35.7 \\
\hline
\end{tabular}

In four of the five experiments reported in this study, the pregnancies terminated spontaneously with the birth of apparently healthy lambs 6 to 36 days after exchange transfusions. Table II presents the following information: the gestational age at the time of the transfusion, the volume of donor adult sheep blood used in the transfusion, the percent of red cells that were classified as adult red cells by red cell elution in fetal circulation at the completion of the transfusion, the duration of the pregnancy following the fetal exchange transfusion, and the fetal outcome. This procedure was clearly compatible with fetal survival in single term pregnancies.

The changes in umbilical venous $\mathrm{O}_{2}$ tension, $\mathrm{O}_{2}$ saturation, and $\mathrm{pH}$ following the exchange transfusion for all fetuses are depicted in figure 2. Table III presents data on the same variables for the pre-exchange and the first post-exchange samples on the six single pregnancies. In addition, values for $\mathrm{pH}, \mathrm{PO}_{2}$, and $\mathrm{O}_{2}$ capacity of two fetuses, Nos. 4 and 56, followed for 36 and 31 days respectively after the transfusion, are shown in figure 3 . The calculated $\mathrm{O}_{2}$ saturation of fetal and adult red cells in the umbilical venous blood of fetus No.4, as well as the umbilical saturation determined directly on the mixed blood, is presented in figure 1; the methods for calculations are reported in the following section. Figure 1 also presents four observations on $\mathrm{O}_{2}$ saturation determined with the Radiometer oximeter on the upper and lower portions of the packed red cell column for comparison with the calculated saturation of adult and fetal red blood cells. Figure 4 presents the percent of $\mathrm{O}_{2}$ saturation in fetus No.56.

$\mathrm{O}_{2}$ saturation decreased approximately $30 \%$ following the exchange transfusion and remained below $70 \%$ for about 15 days without significant change in fetal umbilical venous $\mathrm{pH}$. During the first week following the transfusion, umbilical venous $\mathrm{PO}_{2}$ increased about $5 \mathrm{~mm} \mathrm{Hg}$. In one fetus, umbilical venous $\mathrm{PO}_{2}$ reached 


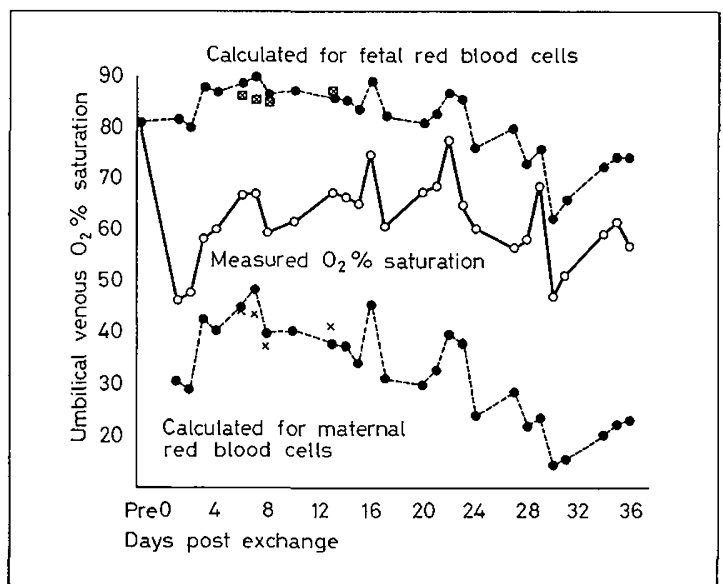

Fig. 1. Umbilical venous $\% \mathrm{O}_{2}$ saturation in animal No.4. The calculated $\% \mathrm{O}_{2}$ saturation for fetal and adult red cells in venous blood following exchange transfusion is also presented, together with the $\% \mathrm{O}_{2}$ saturation determined spectrophotometrically on the upper half $(|\underline{x}|)$ and lower half $(x)$ of the packed red cell mass.

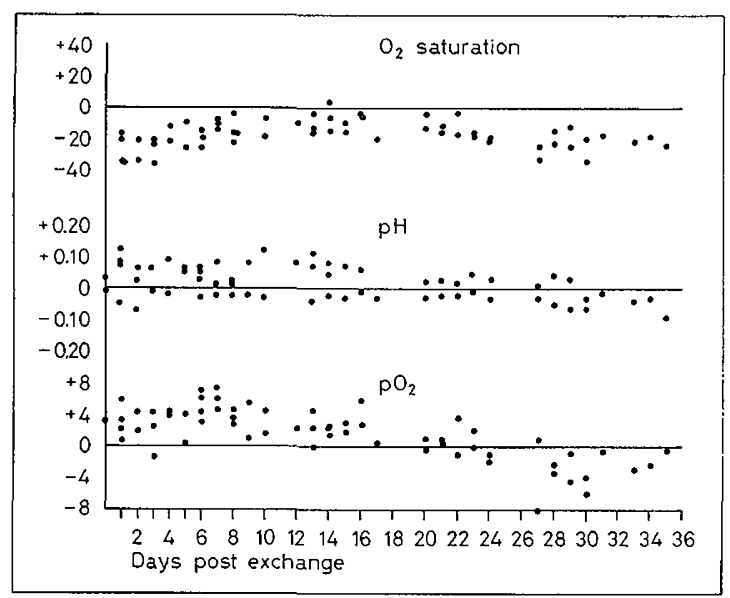

Fig.2. Changes in umbilical venous $\mathrm{PO}_{2}, \mathrm{pH}$, and $\% \mathrm{O}_{2}$ saturation on five fetuses following exchange transfusion. For comparison among different fetuses, data are presented as changes from appropriate control values obtained in the same fetus prior to transfusion.

a peak value of $38 \mathrm{~mm} \mathrm{Hg}$, the highest value for oxygen tension ever observed in unanesthetized sheep breathing room air. Approximately 20 days following the transfusion, a different pattern was observed; a decrease in umbilical venous $\mathrm{O}_{2}$ saturation was accompanied by a decrease in $\mathrm{PO}_{2}$ (figs. 1-4). Since care was taken to use nonanemic adult sheep as donors, there were no significant changes in fetal $\mathrm{O}_{2}$ capacity imme-

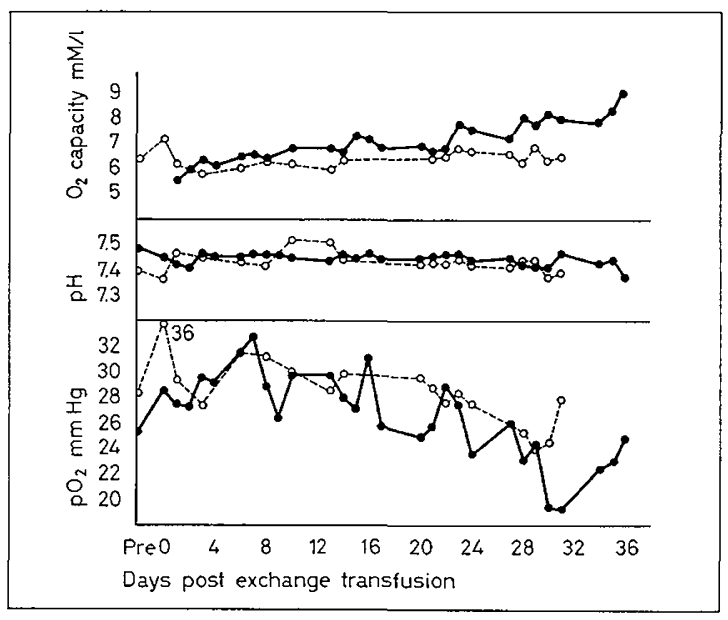

Fig.'3. Umbilical venous $\mathrm{O}_{2}$ capacity, $\mathrm{pH}$, and $\mathrm{PO}_{2}$ in two fetuses followed for 36 days (No.4, solid circles, solid line) and 31 days (No. 56, open circles, broken line) after exchange transfusion. In the lower graph, 36 refers to $\mathrm{PO}_{2}$ on first day post-exchange in animal No. 56 .

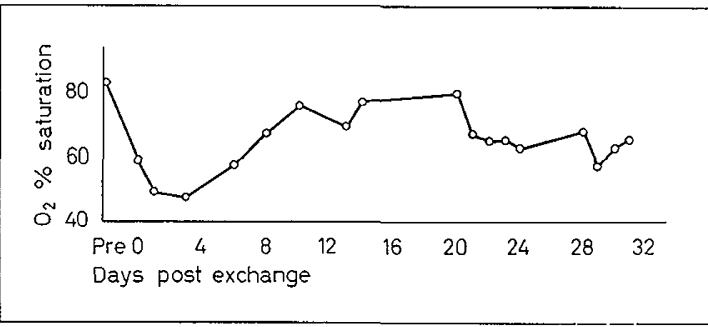

Fig.4.Umbilical venous $\% \mathrm{O}_{2}$ saturation in animal No. 56.

Table IV. Changes in fetal reticulocyte count following intrauterine exchange transfusion

\begin{tabular}{ccc}
\hline \multirow{2}{*}{$\begin{array}{c}\text { Animal } \\
\text { No. }\end{array}$} & \multicolumn{2}{c}{$\%$ Reticulocytes } \\
\cline { 2 - 3 } & $\begin{array}{c}\text { Before } \\
\text { transfusion }\end{array}$ & $\begin{array}{c}6-10 \text { days after } \\
\text { transfusion }\end{array}$ \\
\hline 4 & 3.7 & 8.0 \\
44 & 2.2 & 9.1 \\
$3 \mathrm{H}$ & 2.7 & 6.2 \\
010 & 4.3 & 10.2 \\
56 & 3.4 & 9.0 \\
Mean $\pm 1 \mathrm{SEM}$ & $3.3 \pm 0.4$ & $8.5 \pm 0.7$ \\
\hline
\end{tabular}

diately following the exchange transfusion. Following the transfusion, however, there was a significant increase $(p<0.001)$ in the fetal reticulocyte count, reaching a peak approximately 6 to 10 days following the procedure (table IV).

Measurements of $\mathrm{PO}_{2}, \mathrm{pH}$, and saturation performed on each sample represent estimates of whole blood oxygen affinity. In order to compare these estimates 


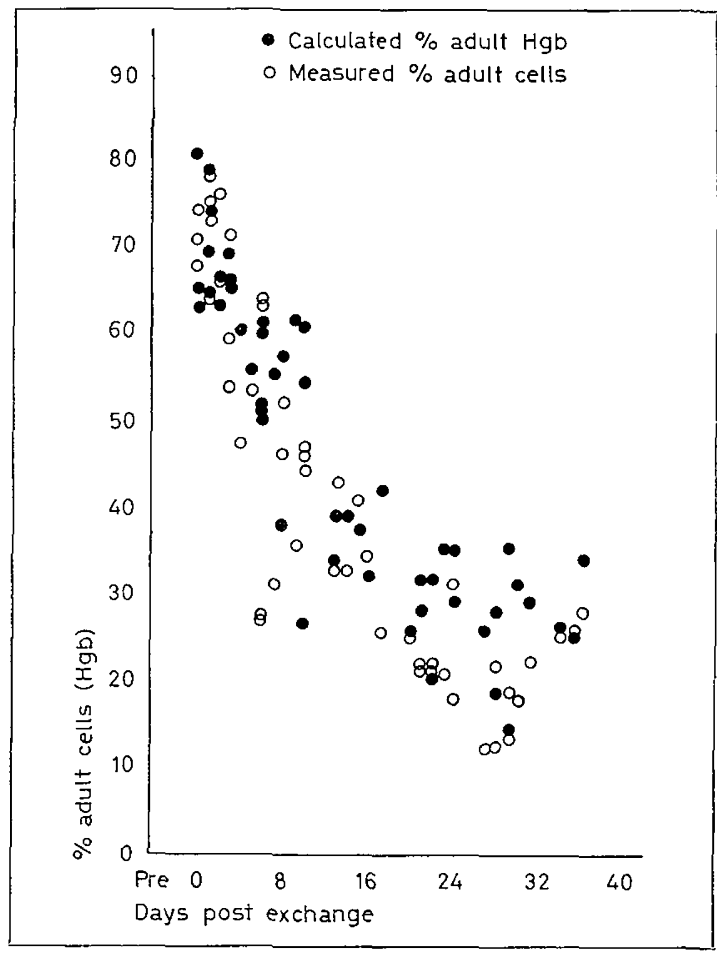

Fig. 5. Changes in \% adult cells determined by red cell elution and \% adult hemoglobin calculated from respiratory gas studies following exchange transfusion in all fetuses.

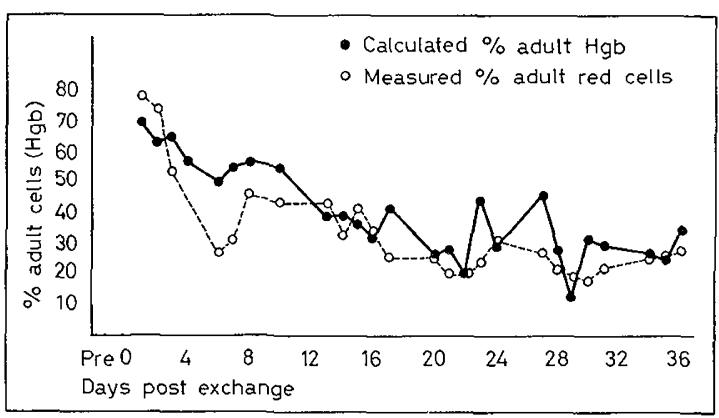

Fig.6. Comparison of \% adult cells determined by red cell elution and \% adult hemoglobin calculated from respiratory gas studies in animal No. 4 .

with known values of oxygen affinity of normal adult and fetal blood, respectively, and to use this comparison to test the hypothesis that adult cells transfused in the fetal circulation retain their own type of $\mathrm{O}_{2}$ dissociation curve, the following procedure was adopted. Each set of measurements was used to calculate the saturation of red cells with adult type $\mathrm{O}_{2}$ dissociation curve $\left(\mathrm{S}_{\text {adult }}\right)$ and the saturation of red cclls with fetal type $\mathrm{O}_{2}$ disso- ciation curve $\left(\mathrm{S}_{\text {fetal }}\right)$. The calculation was derived by two equations developed from previous experiments [8]:

$\log \frac{\mathrm{S}_{\text {adult }}}{100-\mathrm{S}_{\text {adult }}}=\frac{\log \mathrm{PO}_{2}-1.58+0.4(\mathrm{pH}-7.4)}{0.37}$

$\log \frac{\mathrm{S}_{\text {fetal }}}{100-\mathrm{S}_{\text {fetal }}}=\frac{\log \mathrm{PO}_{2}-1.21+0.5(\mathrm{pH}-7.4)}{0.37}$ and

Next, the measured saturation, $\mathrm{S}_{\text {measured }}$, was compared with the calculated $S_{\text {adult }}$ and $S_{\text {fetal }}$ values in order to obtain an estimate of the percentage of hemoglobin with adult type $\mathrm{O}_{2}$ affinity present in the sample:

$\%$ adult hemoglobin $=\frac{\mathrm{S}_{\text {measured }}-\mathrm{S}_{\text {fetal }}}{\mathrm{S}_{\text {adult }}-\mathrm{S}_{\text {fetal }}} \times 100$

Equation (3) is based on the assumption that after transfusion, a sample of umbilical blood is a mixture of two hemoglobins, the $\mathrm{O}_{2}$ affinity of which conforms with Equations (1) and (2) respectively. Comparison between the calculated $\mathrm{S}_{\text {adult }}$ and $\mathrm{S}_{\text {fetal }}$ values and actual measurements of saturation in the lower and upper layers of the centrifuged red cells (fig. 1 ) showed that this assumption was probably correct within tolerable limits of error. The percent of adult hemoglobin calculated by Equation (3) is primarily a relative index of the oxygen affinity of umbilical blood, for it varies between zero (oxygen affinity of the fetal type) to 100 (oxygen affinity of the adult type). There was good correlation between the percent of adult cells present in the blood, determined directly by the red cell elution method, and the percent of hemoglobin with low $\mathrm{O}_{2}$ affinity, calculated according to Equation (3) (fig.5). The mean difference between paired observations ( $\%$ adult cells $-\%$ adult hemoglobin) was $-1.5 \pm 1.0$, which is not significantly different from zero $(p>0.2)$. This correlation shows that the adult cells present in the fetal blood retained an adult-type oxygen affinity even after prolonged exposure to the new environment. A similar comparison between the changes in percent of adult hemoglobin and percent of adult red cells in a single fetus, No.4, was made in order to show the gradual fall ( 75 to 20 ) in percent of adult hemoglobin and cells from the time of transfusion to the day of delivery (fig.6).

\section{Discussion}

The usefulness of intrauterine transfusions of adult blood for the treatment of infants with severe erythroblastosis has been well established. The procedure is still attended by a fairly high fetal mortality that may be related in part to the transfusion and its complications and in part to the severity of the underlying disease. While DAwes [3] has alluded to the apparent 
innocuousness of the lower $\mathrm{O}_{2}$ affinity of adult blood on the fetus, no data have been provided to support this hypothesis.

It is clear from the present study that the low $\mathrm{O}_{2}$ affinity of adult blood is responsible for a fall in $\mathrm{O}_{2}$ saturation in umbilical venous blood and that this effect persists for some weeks while adult red cells are gradually replaced by fetal cells. It is possible that the fetal reticulocytosis seen at 6 to 10 days after exchange transfusion may have been produced by fetal erythropoietin from local renal hypoxia. Nevertheless, the reticulocytosis occurred despite a normal $\mathrm{O}_{2}$ capacity and increased umbilical venous $\mathrm{PO}_{2}$.

It was observed that an increase in umbilical venous $\mathrm{PO}_{2}$ occurred after transfusion. Without this change in $\mathrm{O}_{2}$ tension, the fall in $\mathrm{O}_{2}$ saturation would have been much more marked. At a constant $\mathrm{PO}_{2}$ and $\mathrm{pH}$ of $25 \mathrm{~mm} \mathrm{Hg}$ and 7.40, respectively, the change in $\mathrm{O}_{2}$ saturation from the altered $\mathrm{O}_{2}$ affinity following exchange transfusion would have been approximately $50 \%$ instead of $30 \%$. The reasons for the rise in umbilical venous $\mathrm{PO}_{2}$ following exchange transfusion are unknown. The rise could be the result of some physiologic regulation in response to the low oxygen affinity of the transfused blood, or it could be due to the fact that umbilical vein blood is normally a mixture of streams with widely different saturations. With a significant degree of shunting or uneven perfusion, the production of a lower $\mathrm{O}_{2}$ affinity within the fetal circulation would be expected to lead to an increase in umbilical vein $\mathrm{PO}_{2}$ without necessarily involving a change in umbilical blood flow or fetal $\mathrm{O}_{2}$ consumption. In an earlier study we presented a mathematical demonstration of the role of such factors in determining uterine venous to umbilical venous concentration differences for flow-limited solutes [7]. We intend to pursue the factors that produce an increased umbilical venous $\mathrm{O}_{2}$ tension following exchange transfusion. Such a study may provide a clear demonstration of the role of shunting or uneven perfusion in determining the uterine venous to umbilical venous $\mathrm{PO}_{2}$ difference previously found in both acute and chronic preparations $[1,6]$. The fall in both $\mathrm{PO}_{2}$ and saturation near term (fig. 2) may not be causally related to exchange transfusion but, rather, may reflect changes in uterine circulation.

The oxygen affinity of fetal blood containing a mixture of adult and fetal red cells could be adequately explained by the percent of adult cells determined by the elution method and the affinity characteristics of adult and fetal sheep blood determined by in vitro studies. This study demonstrates that adult red cells present in the fetal circulation for some weeks retain an $\mathrm{O}_{2}$ dissociation curve of the adult type. Similar to fetal hypoxia associated with acute exposure to altitude
[6], the markedly low saturation of umbilical vein blood after transfusion was still compatible with the production of a viable newborn in most of the single pregnancies. In twin pregnancies, however, in which there might have been a less narrow margin of safety, three of the four pregnancies terminated in fetal death in utero. Clearly, adult blood is not as suitable as fetal blood in providing adequate placental $\mathrm{O}_{2}$ uptake. This finding does not imply that the correction of fetal anemia in erythroblastosis fetalis with adult blood does not increase the effective oxygen-carrying capacity of blood even at low oxygen tensions in fetal circulation. It does point out, however, that a significant proportion of transfused red cells with low oxygen affinity will not participate in oxygen transfer. The use of fetal blood for such procedures would obviate this difficulty.

\section{References and $\mathcal{N}$ otes}

1. Battaglia, F. C.; Meschia, G.; Makowskr, E. L. and Bowes, W.: The effect of maternal oxygen inhalation upon fetal oxygenation. J. clin. Invest. 47 : 548 (1968).

2. Breathnach, C.S.: Foetal and neonatal haemoglobins in sheep and goats. Quart.J.exp. Physiol. 49: 277 (1963).

3. Dawes, G.S.: Foetal and neonatal physiology (Year Book, Chicago, Ill. 1968).

4. Klemauer, E.; Brau, H. and Betke, K.: Demonstration von fetalem Hämoglobin in den Erythrocyten eines Blutausstrichs. Klin.Wschr. 35: 637 (1957).

5. Liley, A.W.: Intrauterine transfusion of foetus in haemolytic disease. Brit.med.J. ii: 1107 (1963).

6. Makowski, E. L.; Battaglia, F. C.; Meschia, G.; Behrman, R. E.; Schruefer, J.J.; Seeds, A. E. and Bruns, P.D.: Effect of maternal exposure to high altitude upon fetal oxygenation. Amer.J. Obstet. Gynec. 100: 852 (1968).

7. Meschia, G.; Battaglia, F.C. and Bruns, P.D.: Theoretical and experimental study of transplacental diffusion. J.appl. Physiol. 22: 1171 (1967).

8. Naughton, M.A.; Meschia, G.; Battaglia, F. C. Hellegers, A.; Hagopian, H. and Barron, D.H.: Hemoglobin characteristics and the oxygen affinity of the bloods of Dorset sheep. Quart.J. exp. Physiol. 48: 313 (1963).

9. Supported in part by USPHS Grants HD 00781-04 and $\mathrm{HD}$ 02348-02.

10. Requests for reprints should be addressed to: Frederick C.Battaglia, M.D., Department of Pediatrics, University of Colorado Medical Center, 4200 East Ninth Avenue, Denver, Colo. 80220 (USA). 